\title{
Supreme Court Nominations at the Bar of Political Conflict: The Strange and Uncertain Career of the Liberal Consensus in Law
}

\author{
Donald Alexander Downs
}

Kalman, Laura. The Long Reach of the Sixties: LBJ, Nixon, and the Makings of the Contemporary Supreme Court. New York: Oxford University Press, 2017.

Nominations to the US Supreme Court have become increasingly important and contentious in America politics in recent decades. Reasons include the growing significance of constitutional law to the prospects of political power, accompanied by historical developments in the relative power of the competing party coalitions that have placed even more focus on the composition of the Court. Meanwhile, partisan conflict and stalemate have grown in the party systems and among We the People. In The Long Reach of the Sixties, Laura Kalman explores how the nomination struggles of Presidents Lyndon Johnson and Richard Nixon set the stage for the contemporary conflict besetting nominations and American politics more generally. Building on Kalman's book, this review essay discusses the political and jurisprudential causes and implications of this conflict, with an eye toward what might lie ahead.

Disharmony and conflict are endemic in free societies because of the clash of values, interests, and classes. Indeed, First Amendment jurisprudence in the United States is predicated on the potentially beneficial aspects of verbal conflict. As the US Supreme Court wrote in a famous free speech case regarding protest against the Vietnam War and the draft, "[t]hat the air may at times seem filled with verbal cacophony is, in this sense not a sign of weakness but of strength" (see also Meiklejohn 1965; Huntington 1981). ${ }^{1}$ Conflict can also be a double-edged sword. Writing in defense of the foreign policy consensus that emerged after the Second World War and that generally prevailed until the Vietnam War era, Arthur Schlesinger Jr. (1949, quoted in Lind, 2020, vii) issued a warning that echoes political theory throughout the ages: "The problem of classes is this: Class conflict is essential if freedom is to be preserved, because it is the only barrier against class domination. Yet class conflict, pursued to excess, may well destroy the underlying fabric of common principle which sustains free society."

In "normal" times, governmental social-economic and political conflict in the United States takes place under the auspices of a political regime based on the dominant party system that has held sway during a particular era. The dominant political coalition governs, but it is constantly challenged by the minority coalition and other voices,

Donald Alexander Downs is Alexander Meiklejohn Emeritus Professor of Political Science and Affiliate Emeritus Professor of Law and Journalism, University of Wisconsin-Madison, United States. Email: dadowns@wisc.edu

1. Cohen v. California, 403 U.S. 15 (1971). 
including those within the dominant party itself. But conflict in such situations is constrained by the gravitational influence exerted by the dynamics of the reigning governing party system, which in the terminology of political scientist Samuel Lubell (1965, quoted in Lee 2016, 18-21; see also Klein 2020, 214), comprises "not two equally competing suns" but, rather, "a sun and a moon."

Then there are the more epochal times that witness more fundamental and intense discord that gives birth to a new coalitional party system. Political scientists have described these more fundamental changes in political regimes in American history as the products of "critical" elections or foundational change in the dominant party system (W. Burnham 1970; Aldrich 1995). In each of these situations, a new or competing political party arose that was more responsive to tectonic changes in the political, economic, and cultural life of the country than the tottering party in power. It typically takes two elections to confirm the arrival of a new reigning party system. The most recent dominant system arose after the elections of 1932 and 1936, which spawned the so-called New Deal coalition in response to the profound challenges wrought by the Great Depression and, later, the Second World War. This coalition hitched its wagon to the Democratic party, begetting what legal historian Laura Kalman (1996, 2010,2017 ) has portrayed as a liberal consensus in policy and law that reached its peak with the landslide election of President Baines Lyndon Johnson in $1964 .^{2}$

But what would happen if something else arose, such as "two equally competing suns?" This kind of equilibrium more likely would be less stable, with more built-in conflict, since the weaker power would have less reason to compromise given the relative weakness of the opposition. The third edition of Lubell's book was published in 1965, a pivotal year at the dawn of the New Deal coalition's long, yet ineluctable, unraveling (see discussion below). Some observers have believed that Ronald Reagan's elections in 1980 and 1984 following the Republican presidencies of Richard Nixon (1968-74) and Gerald Ford (1974-76) ushered in a sixth historically dominant party. Reagan's victories were indeed manifestations of the decline of the New Deal coalition and the liberal consensus in policy and law that attended it, and they did herald the arrival of a stronger Republican coalition that has enjoyed somewhat more national and statewide success than the Democratic coalition in recent decades. However, rather than enshrining a new dominant "sun," the period since the 1980s has largely featured deepening dispute and standoff between the parties, accompanied by intensifying political and social polarization. $^{3}$

Though it presents interesting potential that I will mention later in this review essay, the 2020 election appears to have perpetuated the continued stalemate of the parties, each of which is currently undergoing meaningful ferment from within. Does

2. Previous such elections took place in 1800 and 1804 (when the Federalist party gave way to the Democratic Republicans of Thomas Jefferson); 1832 and 1836 ("good feelings" era of relative nonpartisanship replaced by the populist Democratic party led by Andrew Jackson); 1860 and 1864 (Lincoln's Republican party took over from the Democratic party); 1896 and 1900 (the Republican party led by William McKinley settled the economic class dispute).

3. For a discussion of this "puzzle," see Shafer 2003. For years, pundits have been predicting the arrival of a broad and permanent "Democratic majority," only to have to revise their claims in the face of complicating events and factors. See, for example, Judis 2002. Political scientist Stephen Skowronek (1997) defines presidents who challenge existing regimes that are in decline, but which fall short of constituting a new dominant regime as "constructive” presidents. See also Pickerill and Clayton 2017. 
the new decade portend a checkmate for one of the political parties or a continued impasse? Passions are high, especially after the storming of the National Capitol Building in the midst of the confirmation of President Joe Biden's election. As the Constitution's framers understood, good leadership is needed to sublimate the political passion that is always within us into more constructive ends. Is such leadership at hand? In the meantime, the US Supreme Court finds itself situated in the midst of the partisan divides. What does this predicament presage for the constitutional politics of our time?

\section{LAW AND POLITICS}

Like all important endeavors, law is a distinct enterprise with its own set of normative and operative obligations that it forsakes at its peril (see Weinrib 1995; Gillman and Clayton 1999). But because law plays such an important role in American political and civil life-as Alexis de Tocqueville ([1835] 1961) famously observed in the early years of the republicpolitical coalitions strive to have the courts on their side as they pursue their agendas. Law is not simply the "superstructure" of power, but it is also not a fully independent force.

Because of its link to political power and legitimacy, the formation of public law is naturally an essential ingredient of a party system or political regime. The fit between political and legal regimes is not straightforward or deterministic, as we will see. But correlation exists in causation's stead. Political scientists Mitchell Pickerill and Cornell Clayton (2017, 702) write that political regime building "involves constructing new constitutional and legal meanings to validate the new agenda." Mark Graber $(2013,130)$ adds that this relationship can generate deeper constitutional conflicts in history that reflect "the changing circumstances of partisan competition. When new coalitions first gain control of the elected branches of the national government, the presidency in particular, they must typically contend with members of the deposed regime ensconced in the federal judiciary. Constitutional conflicts during this time are often between elected officials and unelected judges."

The failure of the Republican party to achieve dominant coalition status under President Ronald Reagan has engendered continued regime conflict in American politics, a condition that has spilled over into the legal and constitutional realms. This conflict is highlighted by the acrimony that has often, though not invariably, accompanied US Supreme Court nominations in recent decades as well as Supreme Court opinions that deal with issues of high salience for political partisans-seen recently in the highly emotional fight over President Donald Trump's nomination of Justice Brett Kavanaugh to the Court. Trump's successful nomination of Judge Amy Coney Barrett just a month before the 2020 election by a strict party vote in the Senate raised the heat because Barrett replaced the late liberal icon Ruth Bader Ginsburg, thereby tilting the Court even further to the right at the same time that the polity remained divided. Barrett's hearing was relatively peaceful, but it was accompanied in the background by some Democratic calls for packing the Supreme Court and for ending the Senate filibuster in the event of a Democratic "blue wave" sweep in the election.

Though stalemate has characterized the relationship between the parties for the most part in recent decades, an edge goes to the Republicans, who have won the White House in eight of the last fourteen presidential elections. Over at Capitol Hill, Republicans have controlled the Senate for sixteen of the past twenty-six years and have held a majority 
in the House of Representatives for twenty of the past twenty-six years. ${ }^{4}$ The 2020 election narrowed the Democrats' majority in the House, while leaving the Senate split fifty-fifty, making Vice President Kamela Harris's vote decisive in cases of a tie vote on a measure. Overall, however, at the federal level, a divided government-defined as a situation in which no party holds the presidency and both houses of Congress at the same timehas reigned in forty of the fifty years preceding the 2020 election. On this matter, American voters have made their minds up to not make their minds up.

Given this edge in Republican power in the White House and the Senate- the body that must confirm presidential nominees to the federal courts-one would expect the US Supreme Court to lean conservative. But two factors have joined hands to make Supreme Court nominations more explosive in recent decades. First, the balance between the parties regarding Supreme Court nominations has not been as evenly split as control of the presidency and the branches of Congress has been. Remarkably, of the nineteen justices confirmed since 1968, Republican presidents have appointed fifteen, compared to only four confirmations by a Democratic president (Justices Ginsburg, Stephen Breyer, Sonia Sotomayor, and Elena Kagan). Such imbalance of opportunity starts to matter more as the composition of the Court changes over time and as a nominee threatens to influence such salient cases as abortion and campaign finance. Democrats were outraged when Senate Majority Leader Mitch McConnell prevented a Senate vote on President Barack Obama's nomination of DC Circuit Court of Appeals Judge Merrick Garland to the Supreme Court in 2016, the last year of Obama's second term. Trump's nomination of Barrett just a month before the 2020 election added fuel to this fire within a fire, opening the rhetorical door to packing the Court. Though several Republican picks since the late 1960s veered to the left in some jurisprudential domains (for example, Justices John Paul Stevens, Harry Blackmun, David Souter, Anthony Kennedy, and even John Roberts), the more general trajectory of party dynamics and Court coalitions increasingly has led to justices who more closely align with the philosophy of the parties that pick them (Epstein and Segal 2005; Epstein and Posner 2018).

The second condition that has further politicized US Supreme Court confirmations entails the hopes that many political activists have thrust on the judiciary to further policy goals that are more difficult to obtain in the legislative arena, thereby plunging courts deeper into the vortex of political conflict. Arguments over the proper role of the Court and the mission of constitutional law have come to play center stage in the regime politics of our time. One scholar who has devoted her distinguished academic career to probing the implications of this role is Laura Kalman, a legal historian at the University of California, Santa Barbara.

\section{LAURA KALMAN: SUPREME COURT NOMINATIONS AND CONSTITUTIONAL REGIMES}

Kalman has dedicated much of her scholarship in recent years to striving to understand the nature and origins of this legal regime politics, with a focus on both judicial

4. Republicans have also held an advantage at the state level. Today, for example, they hold close to five hundred more state representative seats than Democrats possess and lead by a bit over two hundred in state senate seats. National Conference of State and Legislatures, https://www.ncsl.org. 
politics and the broader vicissitudes of the liberal coalition that reached its peak in the mid-1960s. The main focus of this review essay, Kalman's (2017) The Long Reach of the Sixties: LBJ, Nixon, and the Makings of the Contemporary Supreme Court analyzes a specific, yet representative, aspect of coalitional conflict: how and why the politics of Supreme Court nominations have marked a significant political and legal turn at a pivotal time in American political and constitutional history. The Johnson and Nixon Supreme Court nominations presented in Long Reach serve as a kind of synecdoche regarding the historical fate of what Kalman depicts elsewhere as liberal consensus in policy and law. Kalman acknowledges that Supreme Court picks have often generated controversy in the past, but she maintains that the road to intensified conflict and presidential preoccupation that accompanied such nominations was paved in the politics of the late 1960s and early 1970s. In her words, the book is dedicated to showing "how, between 1965 and 1971, Supreme Court nominees and their confirmations became critical to presidential politics" (Kalman 2017, xi; emphasis added). As Kalman relates, in the decades leading up to the administration of Lyndon B. Johnson (1963-68), who became president following John F. Kennedy's death, "the court and its membership consumed space in presidents' partisan calculations only sporadically. [Even] FDR wasted little time worrying about the Senate's reaction to his prospective Supreme Court nominees or what they would do as justices-which may be one reason that they fought each other so much" (xi).

In two previous books, Kalman addressed the broader liberal legal and political consensus at stake: The Strange Career of Legal Liberalism (Kalman 1996) and Right Star Rising: A New Politics, 1974-1980 (Kalman 2010) (a fourth relevant book, Court Packing and Its Legacy, is under contract and forthcoming as I write). These books focus on the promise posed by the legal liberalism that arose on the heels of the New Deal and on how this promise ultimately fell prey-albeit only partially-to its own tensions and the emergence of new social, legal, political, and economic challenges. Kalman addresses the concrete factors of change while also keeping an eye on the larger picture. She is interested in both the specifics and what we could call the tectonics. And though her normative commitment to liberalism as she defines it is clear, she conscientiously strives to understand liberalism's challengers while acknowledging the conflicts that led to its de-elevation from the dominant to a competing sun. Her work helps us to understand the origins of the partisan conflicts in politics and law that have beset the United States today.

Linked to the New Deal coalition, the liberal consensus reigned in more or less coherent form from the mid-1930s to sometime during the Vietnam era. However messily, this consensus involved foreign policy and relations (the Cold War consensus) as well as domestic matters (on the "vital center," see Schlesinger 1949; see also Kennan 1967-72; Suri 2007). The core of the New Deal coalition included such groups as professionals and intellectuals; activists for stronger national government; southerners; unions; and such identity groups as northern African Americans (southern black individuals could not vote until later), Jews, and Catholics. Though beholden to liberal ideology, the coalition was also pragmatic, a product of its leadership in war and the need to hold together groups from different regions that harbored disparate beliefs. Republicans resisted the consensus in many respects, but they went along with many New Deal programs, especially in the wake of the Second World War, accepting such 
policies as social security, greater regulation of the markets, and an international presence for the nation in the world. (Indeed, both parties courted Dwight Eisenhower to run as their president in 1952.)

Published seven years before Long Reach, Right Star Rising dissected the rise of a reborn and increasingly aggressive conservative and libertarian movement that splintered the liberal consensus from the outside, leading to Reagan's election in 1980 (Kalman 2010). The book also chronicled splits inside the world of liberalism and Democratic politics as this coalition was riveted by conflict over Vietnam, racial tensions, social and moral discord, economic malaise, and political and policy disputes. Right Star Rising joined a long list of other works that have striven to fathom what happened on the way to Reagan's presidency in $1980 .^{5}$ Early in the book, Kalman defines what she means by liberal consensus:

Franklin Roosevelt, Adolf Berle, Abe Fortas, Hugo Black, Allard Lowenstein, Lyndon Johnson, Walter Mondale ... personified liberalism's promise and paradoxes. Assume that liberalism is defined as "an understanding that the federal government has the responsibility, power, and ability to reduce inequality, protect historically oppressed minorities, and balance the private sector's singular focus on making money with a broad concern for the nation's good," as well as a global responsibility to spread capitalism and democracy." (xix, quoting Brinkley 1995)

Legal liberalism is a subset of the broader liberal consensus. Drawing on Gerald Rosenberg's (1991) understanding, Kalman (1996, 2) defined legal liberalism in The Strange Career of Legal Liberalism as "the trust of the potential of courts, in particular the Supreme Court, to bring about 'those specific social reforms that affect large groups of people such as blacks, or workers, or women, or partisans of a particular political persuasion; in other words, policy change with nation-wide impact.' Because of the nation's experience with the Supreme Court under Chief Justice Earl Warren, legal liberalism has been linked to political liberalism since midcentury." 6 As defined, legal liberalism differs from the original jurisprudence of the New Deal in some key respects: whereas the New Deal Supreme Court supported the New Deal agenda largely by virtue of judicial deference to political bodies, legal liberalism embraced courts and legal institutions becoming more actively involved in promoting liberal and progressive change (see the discussion below on "responsive law"). In addition, the new legal liberalism faced the problem of racial oppression in a way that the New Deal coalition had shirked in deference to its southern wing. Among other things, this shift in racial politics helped to homogenize the respective parties, thereby sharpening the differences between them and galvanizing partisan polarization (see, for example, Klein 2020, ch. 2).

5. See, for example, Rick Perlstein's (2001, 2014, 2020) trilogy of books; see also D. Farber 2010.

6. Gerald Rosenberg's (1991) book The Hollow Hope is a liberal scholar's recognition of the limits of the Supreme Court's "heroic" ability to foment progressive change in politics and law. This recognition led other liberal scholars to support political action in favor of an excessive reliance upon judicial review. See, for example, Tushnet 1999. For the view that Rosenberg overstates the case against judicial activism in promoting social change, see the exchanges among Feely 1992; McCann 1992. For a reply, see Rosenberg 1992. 
This change of focus also eventually involved the expansion of the liberal agenda into areas and policies in which less social and political consensus reigned, even in the liberal universe. To mention but one example, though the school desegregation decision Brown v. Board of Education (1954) has attained the status of a so-called "super precedent" because of its widespread acceptance over the years, the same cannot be said of the decisions regarding affirmative action and busing that arose later. ${ }^{7}$ Racial issues underlie many of the trends that I discuss below, though they were not alone in fomenting conflict. Kalman (2010) discusses the Carter administration's difficulties in dealing with the affirmative action, busing, abortion, and other controversial social issues in Right Star Rising. This shift had important implications, especially in a nation undergoing a conservative-libertarian revival, social-economic and political upheaval, globalization, and increasing cultural pluralism. It is useful to treat each of these issues separately, though the reader should bear in mind that they are constituent parts of a broader puzzle that has implications for constitutional jurisprudence and regime status. Let us begin with US Supreme Court nominations.

\section{SUPREME COURT NOMINATIONS: GREATER PRESIDENTIAL CONCERN AND CONFLICT}

Citing legal commentators Sarah Binder and Forrest Maltzman (2009) in Long Reach, Kalman observes that there are two archetypal ways to interpret court nomination politics and jurisprudential change. The Ecclesiastes school perceives "nothing new under the sun," whereas the "Big Bang Theory" school identifies "a breaking point in national politics, after which prevailing norms of deference and restraint in judicial selection have fallen apart" (Kalman 2017, 324). Note that Binder and Maltzman $(2009,7)$ also mention norms simply "falling apart." Kalman is a "Big Banger" on the question of judicial selection and its politics, and much of the trend since Nixon's days lend credence to her position, as seen in the intense partisan conflict that broke out over Reagan's failed nomination of Robert Bork in 1987; President George Walker Bush's successful selection of Clarence Thomas in 1991; the battle over Kavanaugh in 2018; and the affair over Merrick Garland in 2016. The Senate's abandonment of the filibuster rule pertaining to US Supreme Court votes (in 2017) and federal judicial nominations (in 2013) furnish further evidence of the increased preoccupation and conflict regarding judicial nominations.

Kalman also acknowledges that not all nominations are highly contested. The Big Bang Theory school presaged something new, but long-standing historical traditions did not simply disappear. Recall the withdrawal of Harriet Miers's nomination to the Court in 2005, primarily based on widespread concerns by both the left and right that she was unqualified to be a Supreme Court justice. Recall also the vote of ninety-eight to zero to seat arch conservative Antonin Scalia in 1986 at the height of the Regan

7. Brown v. Board of Education, 347 U.S. 483 (1954). On the complex aspects of affirmative action, see, for example, Skrentny 1996. Affirmative action typically has been pushed by courts, administrative agencies, and certain institutions, not by the popular vote. Consider, for example, the rejection in the 2020 election of a referendum restoring race as a consideration in college admissions and government positions in California. 
administration's power, though the Bork and Thomas showdowns followed in short order. (The vote for liberal Justice Ruth Bader Ginsburg in 1993 was ninety-six to three, with one abstention, and sixty-three to thirty-seven for liberal Elena Kagan in 2010, denoting the growing partisan divide.)

Kalman's claim as a Big Banger is also supported by the fact that the Senate had not rejected a Supreme Court nominee between 1930 and 1968. In a vote that helped to set the table for the "critical election" of 1932, the Senate voted (thirty-nine to fortyone) in 1930 against President Herbert Hoover's nomination of US Judge John J. Parker at the hands of a mobilization led by emergent pro-labor and racial justice groups (Watson 1963). Indeed, Parker's defeat was the only outright rejection of a Supreme Court nomination over the course of seventy-four years. Despite this period of relative comity, the political skirmish over Franklin Roosevelt's court packing scheme during his campaign for reelection in 1936 offered a textbook example of Mark Graber's (2013) point about a new majority coalition clashing with a federal bench stacked with appointees drawn from the previous coalition. As the 1936 presidential election approached, the Court had invalidated six federal laws passed by the Democrat-dominated Congress on the ground that the laws presented unconstitutional expansions of federal power in violation of three major constitutional provisions as interpreted by the previous legal regime: the commerce clause of Article I; the Article I doctrine opposing overly broad delegation of the congressional lawmaking power to the executive branch; and the unconstitutional exercise of Congress's taxing power under Article I. ${ }^{8}$

Angered by this judicial roadblock to the New Deal, Roosevelt attempted to put his 1936 landslide win to use by pressuring Congress to pass his "court-packing" plan. The proposal called for Congress to add a new justice for each sitting justice who was at least seventy years old - a move that would just happen to rebalance the Court in Roosevelt's favor. ${ }^{9}$ In a sign of broad public concern for judicial independence, Roosevelt lost this battle. But he won the war without resorting to packing the court, as the Supreme Court's so-called "switch in time that saved nine" witnessed a Court majority reinterpreting the relevant constitutional clauses in New Deal friendly ways (Leuchtenburg 1996). ${ }^{10}$ The Court held true to this doctrinal deference for almost sixty years, not erecting a limit to Congress's commerce power until 1995, albeit rather modestly. ${ }^{11}$

However inept and stumbling they proved to be in the new politics of judicial nomination, Johnson and Nixon took the nomination task seriously because they understood that the direction of the Supreme Court was highly relevant to the prospects of their respective administrations. The Warren Court (1953-69) had used judicial

8. The four most important cases are Schechter Poultry Corp. v. United States, 295 U.S. 495 (1935) (commerce clause and anti-delegation doctrine); Carter v. Carter Coal Co., 298 U.S. 238 (1936) (commerce clause); United States v. Butler, 297 U.S. 1 (1936) (taxing power); Railway Retirement Board v. Alton Railroad Co. 295 U.S. 330 (1935) (commerce clause, due process).

9. Article III of the US Constitution states simply that there shall be "one supreme Court" and "such inferior Courts as the Congress may time to time ordain and establish." The article does not specify any particular number of justices. The number of justices over time has varied between five and ten but has stood at nine since the passage of national legislation in 1869 .

10. See, for example, Jones and Laughlin v. NLRB, 301 U.S. 1 (1937); Wickard v. Filburn, 317 U.S. 111 (1942).

11. See United States v. Lopez, 514 U.S. 549 (1995); see also United States v. Morrison, 529 U.S. 598 (2000). 
power to make the Constitution's equal protections of civil rights and liberty more of a reality in application. ${ }^{12}$ As Kalman $(1996,2017)$ punctuates, Brown v. Board of Education, the famous 1954 school desegregation decision, stood as the emblem of the Warren Court's judicial activism and "heroic" posture. ${ }^{13}$ As we will see below, the legacy of many Warren Court and other liberal decisions have remained relevant for good jurisprudential and normative reasons, thereby supporting the contention that courts have a constitutive role to play in America's republican system of government (see, for example, McCann 1992). But changes in American legal politics and culture in the later 1960s began complicating the story.

Johnson wanted to further the egalitarian project linked to the Warren Court. For his part, Nixon wanted to change the composition of the Supreme Court to make it supportive of his more conservative agenda. ${ }^{14}$ According to Kalman (2017), the state and status of constitutional law somehow just mattered more to Johnson's and Nixon's legacies than it had to their predecessors, albeit for markedly different reasons. It could be said that Johnson and Nixon were transitional figures in this story, foreshadowing what was to come. Johnson's Great Society agenda represented an expansion of the liberal agenda into new domains dedicated to enhancing the power of government and law to increase social, economic, and legal equality. The redemptive project began with the passage of the monumental 1964 Civil Rights Act, the 1965 Voting Rights Act, and other major legislation, helped along by the political pressures exerted by civil rights activists and federal agencies (Rosenberg 1991; Epp 1998). ${ }^{15}$

Inside the administration, Kalman (2017) highlights how Johnson strove to transfer power to name Supreme Court nominees from the Justice Department to the White House, giving him more ability to influence liberal change. ${ }^{16}$ At the height of his power in 1965, Johnson successfully nominated Abe Fortas, a longtime political ally, personal adviser, and Washington legal savant and insider, as associate justice. Fortas replaced Arthur Goldberg, whom the president had persuaded to resign and become the American ambassador to the United Nations. Johnson hoped that the experienced and well-connected Fortas could advise him on how to steer the Great Society's expansion of the New Deal coalition's agenda through skeptical terrain. In June 1967, the Senate confirmed civil rights icon Thurgood Marshall as associate justice in a historic act. As the first African American to serve on the Court, Marshall's selection was, in Johnson's words, "the right thing to do, the right time to do it, the right man and the right place” (Kalman 2017, 96). Marshall's nomination occasioned some resistance,

12. Equalizing legal condition was the centerpiece of this judicial project. See, for example, Cox 1976; Stone 2020. Key doctrinal issues included free speech, criminal process rights, reapportionment and voting, privacy, and equal protection. In terms of judicial regime shifts, the seeds for these decisions were planted by a footnote in United States v. Carolene Products Co., 304 U.S. 144 (1938), footnote 4, which called for enhanced judicial review of laws that improperly discriminated on grounds of minority status or otherwise limited access to the channels of political, legal, and social change, such as voting and free speech.

13. Brown v. Board of Education.

14. As commentators have observed, Nixon's presidency was not consistently ideologically conservative. His liberal or quasi-liberal actions included expanding the federal bureaucracy dealing with the environment and workplace; wage and price controls; détente with the Soviet Union; and declaring: "We are all Keynesians now." Nixon was largely a transitional conservative on the road to Reagan.

15. Civil Rights Act, July 2, 1964, 78 Stat. 241; Voting Rights Act, August 6, 1965, 79 Stat. 437.

16. Along with more traditional data, Kalman (2017) utilizes taped phone conversation among Johnson and members of the administration to capture aspects of this transfer. 
especially from southern senators, but, for the most part, resisters couched their concerns in nonracial terms, suggesting how core legal commitment to racial fairness was becoming more settled in the land. That said, the Senate Judiciary Committee grilled Marshall with numerous questions - an act that was still unusual at the time. In the end, the Senate voted sixty-nine to eleven to confirm.

But a lot was happening in America, as I will emphasize below. A year after Marshall took his seat, the Senate rebuffed Johnson when he endeavored to appoint Fortas to the chief justice's seat, replacing Warren. The nomination fell apart because of both traditional and historically specific factors, including concerns about judicial independence (Fortas had consulted too closely with Johnson over the years, though he was hardly the first justice to cross this line); Fortas's alleged financial shenanigans; and Fortas's judicial support for expanding the rights of criminal defendants during a time of resurgent crime in the streets; Fortas also added his judicial voice to weakening the Court's "obscenity exception" to First Amendment freedoms (Kalman 2017). ${ }^{17}$ The first two critiques raised traditional nonpartisan concerns about judicial ethics, whereas the latter two reflected the rise of social and political differences over sexual morality and crime that had become political hot buttons and harbingers of the cultural wars that have beset judicial nominations to this day (on obscenity, see Downs 1989; Randall 1989). The new wave of cultural wars revived the tensions between secular and traditional religious morality that had festered during the cultural debates over evolution and secularization in the early twentieth century, highlighted by the famous Scopes trial. ${ }^{18}$ Nor did it help that Johnson's popularity was plummeting due to the most explosive issue in the 1960s: the war in Vietnam.

Upon winning the White House in 1968, Nixon was determined to reorient the course of American public law in a conservative direction, and his negative feelings toward the Warren Court's liberalism were shared by a conservative movement picking itself off the matt after the knockdown it had suffered with Republican Barry Goldwater's crushing defeat in the 1964 presidential election. The day after this defeat, the New York Times (1964) wrote a rest-in-peace editorial over the putative grave of the modern conservative movement: "Barry Goldwater not only lost the Presidential election yesterday but the conservative cause as well. He has wrecked his party for a long time to come and it is not even likely to control the wreckage." But, as a transitional figure, Nixon was not entirely sure of his beliefs - at least compared to later Republican presidents - and his process for judicial selection was often sloppy and chaotic, even when it succeeded. Kalman provides fascinating detail about the nomination agonies that Nixon suffered. Nixon also had to deal with a Senate controlled by the Democrats.

17. In 1972, CBS reporter Fred Graham portrayed the Warren Court's criminal defendant rights decisions as a "self-inflicted wound" because of the crime wave that took place in their background, triggering the "politics of law and order" that was to last for four decades (Graham 1972).

18. Scopes v. State of Tennessee, 154 Tenn. 106, 289 S.W. 363 (1927). The Supreme Court of Tennessee ultimately dismissed the Scopes prosecution in words that might be relevant to the nation's conflicts of 2020: "The Court is informed that the plaintiff in error is no longer in the service of the State. We see nothing to be gained by prolonging the life of this bizarre case. On the contrary, we think the peace and dignity of the State, which all criminal prosecutions are brought to redress, will be better conserved by the entry of a nolle prosequi herein. Such a course is suggested to the Attorney-General." Walter Lippmann (1929) poignantly portrayed this earlier cultural clash in his classic book, A Preface to Morals. For an update on cultural and moral wars, see Roy 2020. 
Nixon's nomination politics began auspiciously enough, winning a quick Senate vote in favor of conservative Warren Burger to replace Warren as chief justice in 1969 (Kalman 2017, 74-73). But this win was soon followed by the defeats of Clement Haynsworth and G. Harold Carswell, after which the Senate did confirm the pick of Harry Blackman as associate justice in 1970. (A fateful pick due to Blackman's leadership role in deciding Roe v. Wade, the 1973 abortion case. $)^{19}$ Nixon hoped Haynsworth, a southerner and conservative, would help to secure the president's electoral "southern strategy," which was predicated upon appeals to southern voters to rebel against the federal government's efforts to advance racial justice and to limit state discretion. It was also meant to ward off the challenge posed by former Alabama Governor George Wallace's racialist presidential candidacy in 1968 (Phillips 1969; Klein 2020). Not surprisingly, Haynsworth was opposed by labor and civil rights groups, which were leading pillars of the Democratic coalition. And, like Fortas, he was accused of engaging in improper financial transactions while serving as a federal judge. The Senate Judiciary Committee also interrogated Haynsworth, adding precedent to this emerging tradition that became a weapon of the "Big Bang." Thirty-eight Democrats voted against Haynsworth, along with seventeen Republicans. For his part, Carswell's nomination floundered because of racial comments that he had made in previous years and because he was considered mediocre. Thirty-eight Democrats and thirteen Republicans opposed Carswell.

Alas, Nixon's nomination travails were not over. Shortly after Blackman's success, Justices John Marshall Harlan and Hugo Black stepped down, presenting Nixon with even more opportunity to reshape constitutional and public law. But his first two leading candidates were withdrawn when the American Bar Association's (ABA) House of Delegates reported them as being "unfit." (One of them-Hershel Friday-had even once served on the ABA's House of Delegates!) This failure was followed by the successful nominations of William Rehnquist and Lewis Powell, whose conservative credentials were widely known. After all the dust had cleared, Nixon had stumbled his way to obtaining four Supreme Court appointments. The Supreme Court was now poised to pursue a new, more conservative direction in constitutional law, but its course has not always reflected a purely conservative political regime.

The skirmishes over Supreme Court nominations provide but one window into the broader issue that animates Kalman's (2017) work and that of many other observers: the fraying of the liberal consensus in law and policy that lay at the heart of the New Deal coalition and its extension by Johnson. The forces involved in this process are still with us, although new players and claims have entered the fray.

\section{LIBERAL CONSENSUS MEETS THE LATER 1960S AND ITS AFTERMATH: POLITICAL ASPECTS}

The politics and law of the 1960s produced many liberal successes that have continued to enjoy fundamental consensus. In addition to judicial expansion of equal protection and such civil liberties as free speech and the passage of the Civil Rights Act and the Voting

19. Roe v. Wade, 410 U.S. 113 (1973). 
Rights Act already mentioned, a sampling of new legislation at this time includes the 1964 Food Stamp Act; the 1968 Fair Housing Act; the 1965 Social Security Amendments that created Medicare and Medicaid; and the rise of national environmental and occupational regulation under the auspices of the Nixon administration-the latter showing how much less polarized the political parties were back then compared to now. ${ }^{20}$

Nonetheless, expanding the liberal consensus to include the furtherance of the Warren Court's unfinished business in a time of social, political, and economic upheaval courted controversy for a host of political reasons. The United States entered the aftermath of the Second World War in an extraordinary position of international political and economic power. This fortuitous circumstance established the United States as the pillar of the emergent "liberal world order" (Kagan 2012). But events beginning in the second half of the 1960s precipitated erosion of the liberal coalition's expansion of the New Deal. The title of historian William O'Neil's (1971) book on the 1960s captures a key aspect of what happened: Coming Apart. O'Neil chronicled the upheavals of the 1960s in lively and caustic prose, presenting a kind of Greek chorus background to Kalman's later works.

Many factors combined to weaken the liberal consensus, including the unpopular Vietnam War and the draft; rising crime in the streets (Graham 1972; Stuntz 2011); political assassinations; urban riots and the violence inflicted by police and rioters at the Democratic national convention in Chicago in 1968; the sexual revolution, accompanied by the explosion of pornography and obscenity; ${ }^{21}$ campus upheaval; and the emerging culture wars that included debates over the meaning and face of patriotism, foreshadowing shifts in blue collar America toward the Republican party and economic elites toward the Democrats. In reaction, conservatives mobilized, and sundry traditional liberals moved right (many of the prominent "neoconservatives" the 1970s and 1980s had once touted liberal and even socialist beliefs [Steinfels 1979]).

As the 1960s wore on, liberalism also began to turn on itself in a process that would grow in intensity in the ensuing decades, mirroring later internal conflicts in conservativism. Upset at conservative resistance and backlash, the continuance of the Vietnam War, and the slow pace of political and social change under liberal legal reform, factions on the left began to push for a more progressive form of law and policy that was more critical of what they considered the telling abuses of American power and of liberalism itself. The liberal Kennedy and Johnson administrations had led the country into the Vietnam War, making the "Liberal Establishment" the first target of the 1960s' left (Downs 1999). This division grew over subsequent decades, resulting in today's tensions between the Democratic party's traditional liberal faction and the new progressive faction.

Kalman (2010) dissects the journey that led to Reagan in Right Star Rising, addressing the beleaguered interlude of Jimmy Carter's presidency from 1977 to 1981 along with a host of other events. ${ }^{22}$ Reagan's administration presided over recovery on the economic and foreign policy fronts, highlighted by setting the stage for the fall of the Soviet Union that took place in Republican President George H. W. Bush's

20. Food Stamp Act, August 31, 1964, 78 Stat. 703; Fair Housing Act, April 11, 1968, 82 Stat. 73.

21. All societies harbor ambivalence regarding certain aspects of sexuality and its portrayal. For an insightful analysis of this universal tension, see Randall 1989; see also Downs 1989.

22. Carter was also a transition figure of sorts, being both an "outsider" and a supporter of economic deregulation that helped to pave the way for Reganomics. 
administration, which succeeded Reagan's. ${ }^{23}$ Reagan's ascension ramped up the ideological consistency and intensity of the Republican party. However, he was also comfortable making deals and working across the aisle; both Bush and Democrat Bill Clinton continued Reagan's neoliberal economic policies that favored market freedom, international trade, and regulatory relief and efficiency. By the end of Clinton's presidency, both the United States and neoliberalism seemed to be on top of the world. In retrospect, Reagan was a transitional figure in terms of partisan polarization.

Alas, with some ebbs and flows, the years since Reagan's presidency have brought increasing partisan polarization regarding the role of government and how to respond to the growing challenges to American power, the detailed history of which are beyond the scope of this review essay (Klein 2020). ${ }^{24}$ A short list of causes includes the controversial wars against terrorism in response to the terror attacks of September 11, 2001; the impeachments of President Clinton (in 1998) and Trump (in 2019); heightened partisan voting in Congress (for example, on health care, taxes, and regulatory policies; on the stimulus policy after the Great Recession of 2008; on cultural issues; and so on); ongoing tensions regarding race, focusing on criminal justice; and the explosion of talk radio, 24/7 cable television news, and social media that have amplified ideological rage and omnipresence.

In addition, national and international trends have conspired to encourage Trump's and Bernie Sanders's quite different populist-related challenges to their respective parties in 2016. ${ }^{25}$ The neoliberal, free trade policies of previous administrations had not only renewed economic growth but also contributed to empowering China's economic and technological rise, which took jobs from swaths of the American working class. Meanwhile, neoliberal elites made non-elite classes feel culturally disrespected (Lind 2020). Biden's win in 2020 was premised on a return to "normalcy," but national tension was high as Biden took office. Political scientists and other commentators have expressed astonishment at how much more polarized the electorate has become over the last two decades, which is especially the case for politically active citizens (Pew Research Center 2017). A partial list of exacerbating, interconnected factors in this trend includes:

- The parties themselves have become more ideologically driven and polarized, though the inner splits as of 2020 might signal meaningful ferment even inside the parties. Before the 1960s, the Republican party included northern liberals and business conservatives, and the Democratic coalition included conservative southerners and culturally conservative working-class members along with liberal northerners, people of color, and culturally liberal

23. In 1992, Francis Fukuyama (1992) famously proclaimed "the end of history," by which he meant the historical triumph of liberal democracy, with the United States at the helm. Alas, inconvenient events conspired to betray Fukuyama's hopes, not the least of which were the precipitous rise of communist China, the onset of the "Great Recession" of 2008, and the onslaught of terrorism highlighted by 9/11. Fukuyama was not the first prominent author to be wrong after announcing the triumph of liberalism. Daniel Bell's (1960) The End of Ideology appeared in 1960, right before ideological conflict began to rock the decade.

24. Some scholars claim that Republicans played their part by enforcing more ideological conformity in the House after they swept to power in the 1994 midterms, ending four decades of Democratic control in that body. The impeachment of Clinton followed in the House in 1998, along with non-conviction in the Senate. See, for example, Hacker and Pierson 2019.

25. Pat Buchanan's challenge to George H. W. Bush in 1992 represented a cultural and economic critique of neoliberalism, as did Ross Perot's third party challenge, which helped to elect Clinton, who received only a plurality of votes. 
intellectuals. After the Democrats' purge of Dixiecrats and the cultural battles of the 1960s, each party became more ideologically consistent. As Ezra Klein $(2020,204)$ writes, in the past, "[o]ur core cleavages played out within the two parties rather than just between them. But those days are gone."

- At the same time, judicial nominations became increasingly more contested over time, especially after the mid-1980s, and justices' ideological adherence to nominators' expectations became more consistent, though with important caveats and exceptions mentioned below (Epstein and Segal 2005; Kalman 2017; Epstein and Posner 2018).

- Electoral voting has become noticeably more "negative" over time, meaning that voters are more inclined to base their votes on opposing the other side rather than supporting their side (Abramowitz and Webster 2016; Abramowitz and McCoy 2019). This process is related to what Bill Bishop and Robert Cushing (2008) call the "big sort" of the country into red and blue parts, ideologically, socially, and even geographically (see also Levendusky 2010).

- Politics has become more "national," especially since 1968 due to such factors as the decline of local parties, weaker local media arising from the mushrooming of social media, and the commandeering of revenues from advertising by such social media giants as Google and Facebook-revenues that used to go to the actual producers of news (Hopkins 2018; Klein 2020, 210-13). Furthermore, national politics is much more about "identity" and tribal commitment than it has been in previous decades. Nationalizing issues places more pressure on national institutions, including courts, to deal with problems once handled locally.

- The Internet and social media have broken the so-called "Overton Window," which social media theorist Clay Shirky defined in a Tweet as "the ability of elites to determine the outside edges of acceptable conversation. Quoting Shirky, Benjamin Thompson (2016), a specialist on the social and political and cultural implications of social media and high tech, writes: "These limits were [once] enforced by party discipline, and mass media whose economics meant political centrism was the best way to make money. This was BC: Before Cable." In his widely read essay in Strategery, Thompson chronicles how the Internet and social media have weakened political party control over the electoral process, moving the country from a polity in which the "party decides" to one in which newly aggregated "voters decide" (Cohen et al. 2008).

- These and other factors have contributed to the present situation, which is marked by what political scientist Frances Lee (2016, quoted in Klein 2020, 217) calls "insecure majorities." When "neither party perceives itself as a permanent majority or permanent minority," partisan conflict intensifies.

These trends help to explain the dynamics behind Kalman's (2017) Big Bang postulate. As we will see in the next section, this phenomenon is exacerbated if courts remain important arbiters of public values. A key question emerges: how do the vicissitudes of public and constitutional law fit into the story of spiraling partisan conflict?

\section{LIBERAL CONSENSUS AND THE VICISSITUDES OF “RESPONSIVE LAW"}

Reagan's presidency was not just about economics, but it also supported more conservative cultural and legal values, including changes in constitutional law. Led by Attorney General Edmund Meese, Reagan's administration furthered Nixon's philosophy of allegiance to the original constitutional text - code terminology for judicial restraint in constitutional areas that are uncongenial to the rising right. In addition 
to unleashing a flurry of new scholarship on constitutional interpretation, the right mobilized a network of conservative and libertarian legal organizations, led by the Federalist Society, which came to play a significant role in shaping legal ideas and judicial nominations (Meese 1986; Teles 2008; Kalman 2010). As Pickerill and Clayton (2017, 705) write, “[b]eginning with Richard Nixon's 'southern strategy,' and culminating in the election of Ronald Reagan, Republicans were able to exploit the fissures in the Democratic Party, begin defining several emerging cleavage issues, sharpen the differences between themselves and the Democrats, and court the voters who eventually became known as 'Reagan Democrats."'

Two years before Reagan's electoral victory over Jimmy Carter, Philippe Nonet and Philip Selznick (2005) published Law and Society in Transition: Toward Responsive Law, a book that captured the normative and policy aspirations of the type of "responsive law" heralded by many of the Warren Court's devotees. The concept of "responsive law" bears great resemblance to Kalman's (2017) conceptualization of the liberal project in law and policy, which featured a more aggressive role for courts than the New Deal had envisioned. In retrospect, however, Law and Society in Transition summons images of Georg Hegel's (1821, preface) famous maxim that "[t]he owl of Minerva spreads its wings only with the falling of the dusk." That is, the most definitive understanding of a historical epoch often prevails at its twilight, or when it becomes challenged, as we reflect back on what has transpired freed from the fog of history on the make.

Nonet and Selznick (2005) distinguished two types of modern law: "responsive law" and "autonomous law." 26 Though admittedly simplistic, these "ideal types" are heuristically useful for our purposes. Autonomous law entails legal institutions striving to maintain a measured distance from political engagements and to remain as neutral as possible regarding the substantive content of law, leaving it up to political bodies to provide the content for, and consent to, change. (Courts are to "interpret" law, not "make" it.)

As Nonet and Selznick $(2005,14)$ put it, responsive law commits legal institutions to being the "facilitator [of] response to social needs and aspirations"; legal institutions, including courts and administrative agencies become leading instruments of progressive change and social justice, bypassing elected leaders in the legislatures if necessary or perhaps pursuant to broad delegations of power from legislatures. To a meaningful extent, the drive for responsive law epitomized what Lawrence M. Friedman (1985) labeled "total justice" in his book of that name on tort law reform (see also Kagan 2005). Responsive law is a heightened, "high-risk" liberal attempt to enlist courts and other legal institutions in an effort to fill in the disparity that stretches between liberalism's aspirations of justice and equality and its follow through in application: liberalism's tragic gap (Nonet and Selznick 2005, 117). ${ }^{27}$ As a tool in closing the gap, responsive law not only has noble aspirations, but it also has normative and practical limits. Practical limits concern the problems that courts encounter trying to fashion

26. They also discuss "repressive" law, in which law is not autonomous but, rather, simply a tool or weapon serving entrenched political power. Which form of law is predominant in a regime depends on history and the vantage point of the viewer.

27. In a book published a year before Law and Society in Transition, and which parallels its historical and legal reasoning in many respects, Roberto Unger (1976) provided a deeper, more pessimistic psychological and philosophical interpretation of the gap between liberalism's ideals and its actuality, portending what would be called post-liberalism. 
viable decisions in the complex policy areas in which responsive law courts venture. ${ }^{28}$ Normatively, responsive law poses issues of democratic consent in a changing political context, and this normative issue also has political implications.

A tool of total justice —or at least of narrowing the tragic gap —is the judicial use of progressive forms of such doctrines as "substantive due process" or what Thomas Grey (1978) calls the "unwritten" Constitution. Nonet and Selznick $(2005,16,67)$ cite "substantive justice"-distinguished from "procedural justice"—as essential to the purpose of responsive law. Such resorts involve courts reading substantive values into the due process and other more open-ended clauses in order to achieve goals not clearly specified by the Constitution's text or by legislative agendas. The republican aspects of American constitutionalism dictate judicial intervention when state action violates constitutional norms that are reasonably derived from the four corners of the constitutional text or settled doctrinal precedent, but controversy can arise when a decision's derivation from these corners is less than self-evident.

The US Supreme Court did engage in such adjudication during the controversial "Lochner" era to protect vested property interests, only to abandon it during the constitutional crisis over the New Deal (Corwin 1948; Gillman 1993). ${ }^{29}$ In the wake of Lochner's demise, the Warren Court resurrected a new form of "Lochnerizing" in the domain of civil liberty and rights, most notably relating to the right to privacy. Resort to such jurisprudence has hardly been the exclusive tool of the Warren Court. For example, the Burger Court expanded the Warren Court's discovery of the right to marital sexual privacy in Griswold $v$. Connecticut to a more generalized right to sexual autonomy (Eistenstadt v. Baird) and the right to an abortion (Roe v. Wade), and, in Moore v. City of East Cleveland, it ruled against narrow government definitions of "family." 30 The erstwhile conservative Burger and Rehnquist courts were quite "active" and "responsive" in their own ways (Keck 2004).

It is important to note that judicial deployment of substantive due process and kindred tools of adjudication can fill in constitutional gaps, but they are inherently controversial for several reasons. In addition to the concern that they amount to judicial "making of law" rather than simply "applying" the law, they also involve elevating certain claims to rights over others in a context not governed by a written text that has been adopted by a process of democratic consent. Such elevation can work well enough when it is consistent with a dominant political regime (the "sun") or when it is carefully developed "doctrinally" over time in a manner that acknowledges its relatively tentative nature while building up a precedential record that achieves doctrinal acceptance over time. ${ }^{31}$ But it raises legitimacy questions when contrary or neglected interests in a regime begin to raise their voices. As Kenneth Kersch (2004) portrays in Constructing Civil Liberties, something was both gained and lost in the historical transition away from the judicial era of

28. In the same year as Nonet and Selznick published their book, Donald Horowitz (1977) published The Courts and Social Policy, which presented influential empirical critiques of judicial attempts in complex policy fields.

29. Lochner v. New York, 198 U.S. 45 (1905).

30. Griswold v. Connecticut, 381 U.S. 479 (1965); Eisenstadt v. Baird, 405 U.S. 438 (1971); Roe v. Wade; Moore v. City of East Cleveland, 431 U.S. 494 (1977).

31. See, for example, Souter's concurrence regarding the right to die in Washington v. Glucksburg, 521 U.S. 702 (1997), and Harlan's dissent to the Court's jurisdictional ruling in Poe v. Ullman, 367 U.S. 497 (1961). 
"economic liberty" to the modern civil liberty regime that has downplayed economic rights in favor of "human rights" (see also Siegan 1980, 2017; Wilkinson 2009; and the discussion of the recent Second Amendment cases below). A more philosophical take is Walter Berns's (1982) critique of Thomas Grey's (1978) position. Drawing on several classic social contract theorists, Berns argues that "unwritten" constitutional norms lack the coherence and legitimacy that come from the public act of ratifying constitutional language in an actual public text. They possess the status of mere "private" judgments lurking in the precontractual state of nature rather than the binding status of the "public" judgments embodied in the written social contract. ${ }^{32}$

As Berns's former student Gary Jacobsohn (1984) has observed, however, judicial resort to "unwritten" values has been habitual in history, partly because of the inherent normative element in law; Jacobsohn emphasizes that such judges typically also cite written text to support their invocations of non-textual values. ${ }^{33}$ (Chief Justice John Marshall is a leading example in American constitutional history.) And as anyone who has taught constitutional law knows, reliance on the written text hardly eliminates controversy over interpretation and the need for judgment. Constitutional law is notoriously open to interpretive disagreement, and constitutional reason resides somewhere between text and considered judgment. ${ }^{34}$ As arch originalist Amy Coney Barrett stressed in her confirmation hearing, even dedicated originalists often reach different conclusions applying originalist methodology, and a substantive due process case can become legitimate if it has the ingredients to become a "super precedent." 35

Though motivated by the desire to narrow liberalism's moral achievement gap, a key motor of "responsive law" change is supra political in the sense that it enlists courts and administrative agencies in the quest for social change and justice, often circumventing the difficulty of forging democratic consent through the interplay of public opinion and the legislative process - in other words, through "politics." (On public interest lawyers' drive in this era toward a "judicial model of the state," (see McCann 1986, 114). In the introduction to the 2005 re-publication of Law and Society in Transition, Robert A. Kagan (2005, xii) observes that, "[b]y inviting and responding to legal advocacy that calls for legal change, institutions

32. This understanding of social contract theory has ancient roots. See, for example, Aeschylus's Oresteia: outside of agreed upon public law, moral claims can fall prey to the moral "furies." Pushing Berns's (1982) claim regarding the subjective quality of references to "unwritten" constitutional values to a more controversial level, Jeremy Waldron (1999) later stipulated that judicial review was suspect even when it dealt with a written constitutional text. Among other points, Waldron points to the fact that, whereas physical science has a more or less agreed upon method of resolving differences of findings—at least compared to moral disputes-no such consensus pertains to normative disputes embedded in constitutional language regardless of whether the norms are written or unwritten. See also John Hart Ely's $(1980,58)$ pithy observation: "We like Rawls, you like Nozick. We win, 6-3. Statute invalidated." On how the method of resolving disputes in physical science can also be messy, see Oreskes 2019.

33. Martin Shapiro (1986) has discussed the ways substantive due process elements are embedded in many areas of modern constitutional jurisprudence-for example, privacy; takings clause; equal protection categories; administrative law's "hard look" doctrine; incorporation of the Bill of Rights.

34. Many prominent works discuss the various methods or models of constitutional interpretation. See, for example, Bobbitt 1982; Murphy, Fleming, and Harris 1986; Whittington 1999.

35. Applying John Rawls's (1971) concept of the "original position" helps to clarify the issue. If one is ignorant of what direction substantive due process review will take in the future, would one be willing to take a chance on supporting it given that its direction could be detrimental to one's values and that the decision came from a divided, non-elected body? John Hart Ely $(1980,58)$ mocks such review with a telling parody: "We like Rawls, you like Nozick. We win, 6-3." 
in a regime of responsive law redistribute power, blurring autonomous law's sharp distinction between law and politics. For this reason, as Law and Society in Transition acknowledges, responsive law is a 'high risk' mode of governance that can undermine the legitimacy of legal institutions by making law less stable, more 'malleable and flexible."' Reflecting on this tension in her book The Strange Career of Legal Liberalism, Kalman (1996) portrays the earnest ways in which liberal legal scholarship struggled up to 1996 with reconciling a substantive progressive policy role for law with law's deep tradition of political neutrality - for example, "neutral principles"; "legal process"; "consensus adjudication"; "law and" society, economics, and so on; "historical analysis"; legal hermeneutics"; "critical legal theory"; and other theories —each with varying degrees of tentative success.

From the perspective of political regime theory, the institutional activist aspect of "responsive" law is at least partially camouflaged when its content is consistent with the purposes of a dominant regime. Consolidated power bestows a quasi-objective, neutral-appearing face upon the judicial or administrative embodiment of substantive values. But, as a regime's support weakens, the person(s) behind the curtain become more visible, fomenting the image of government by men and women-bureaucrats and unelected federal courts - in tension with law arising out of the democratic consent of the governed. Not surprisingly, it was after the fraying of the New Deal coalition during the conflictfraught 1960s and 1970s that legal scholars also started spilling more ink over the socalled "democratic majoritarian difficulty" or "dilemma." This scholarship raised questions about the legitimacy of change engineered-or engineered too much-by institutions that were less directly accountable to the "electoral connection" that is central to democratic theory and legitimacy (Bickel 1962; Kramer 2004). Similarly, constitutional scholars began a hearty debate over the pros and cons of judicial activism and the proper nature of constitutional interpretation. Just how fixed is constitutional meaning? Should originalism prevail over a "living constitution?" Is there an ascertainable and normative distinction between "interpretivism" and "non-interpretivism"? Or is it a matter of what lies in the eyes of the beholder or who controls the levers of power?

Kalman (1996, ch. 3) discusses a special meeting of major legal scholars at Yale Law School in 1981 as a pivotal event that symbolized the "beginnings of palpable angst among law professors" regarding the epistemological underpinnings and legitimacy of legal and constitutional theory. The dam containing consensus had fractured, and attempts to heal the breach by reconciling law and activism flowed. In a widely discussed book published in the middle of Reagan's two terms, constitutional theorist Michael Perry (1984) struggled conscientiously to reconcile "non-interpretive" review - a species of substantive due process - with majoritarian rule by proposing that "non-interpretive" decisions should be made subject to extraordinary rejection by Congress. Perry conceded the fact that a large portion of judicial review in the human rights area had been "non-interpretive" by traditional standards. So he made his case on straightforward "functional" moral and non-interpretivist grounds independent of the Constitution's four corners. Despite its occasional history of moral failure, ${ }^{36}$ Perry

36. To wit, Dred Scott v. Sandford, 60 U.S. (19 How.) 393 (1857), the decision in which the Supreme Court held that slaves were the property of their owners, not human beings for constitutional purposes, and Plessy v. Ferguson, 163 U.S. 537 (1896), in which the Court upheld public segregation in the South based on the "separate but equal" doctrine. 
concluded that the historical balance favors accepting the Supreme Court as a "moral prophet" in law (98). ${ }^{37}$ In 1980, a former Earl Warren clerk, John Hart Ely (1980), argued for a form of non-interpretivism that addressed the majoritarian dilemma by espousing a "representation-reinforcing" theory of judicial review that limited noninterpretive review to the reinforcement and promotion of open democratic process and non-discrimination. ${ }^{38}$ These prominent scholars were but two voices in a widening debate over the pros and cons of various forms of "substantive due process," the functional and normative role of the Court, and what constitutes a legitimate form of constitutional interpretation (see, for example, Berger 1977; Choper 1980; Bobbitt 1982). This literature was rife with intellectual ferment and engaging legal and normative dispute. It also reflected the fact that the intensification of political regime conflict had spilled over into the realm of constitutional theory and interpretation.

The case that engendered the most conflict regarding substantive due process and the concomitant interpretivism/non-interpretivism debate is Roe $v$. Wade, the decision that made abortion a constitutional right. Roe was pivotal in the clash over the nominations of Bork (1987), Thomas (1991), Kavanaugh (2018), and Barrett (2020), and it serves as a kind of synecdoche of the contemporary conflict between progressive and conservative politics and law. Kalman (1996) begins The Strange Career of Legal Liberalism by quoting Pamela Karlan, who later testified as an expert witness against President Trump in the House impeachment hearing in late 2019. Karlan wrote that "Roe v. Wade has served as a lightning rod for modern constitutional law. It is the Brown v. Board of Education of our generation" (7).

But, unlike Brown, Roe has continued to be a lightning rod since its inception in 1973. Roe's underpinnings more clearly rested on an "unwritten" Constitution, thereby raising questions about such things as the nature of valid constitutional interpretation and the tension between social change via legislative give and take and change engineered by courts. Also, the ontological status of the fetus as a distinct form of human life persists as a moral challenge to pro-choice advocates (Arkes 2002; Dyer 2013), as does the integrity of women's bodies and choices on the other side of the ledger (Thomson 1971; Rubenfeld 1989). One's position on abortion often serves as a symbol of deeply held normative beliefs and cultural obligations, including the meaning of womanhood and motherhood (Luker 1984). The abortion issue galvanized new political coalitions while drawing on preexisting partisan differences, deepening its political salience for activists on both sides (O'Brien 2019). Meanwhile, the general public has consistently supported compromise regarding this highly sensitive issue of policy (Bruce 2020). In the 1992 case Planned Parenthood v. Casey, a divided Court tendered a peace treaty

37. Perry uses moral prophesy language throughout his book. Some constitutional casebook writers began accepting "ethical" jurisprudence as a valid mode of constitutional interpretation around the same time. See, for example, Murphy, Fleming, and Harris 1986.

38. John Hart Ely's (1980) model was premised on the famous Carolene Products, footnote 4. Footnote 4 is renowned for heralding the shift in Supreme Court protection away from the constitutional protection of economic interests to the protection of civil rights liberties and equal protection under the law, as showcased by Brown v. Board of Education and other cases. Ely's model of review received its degree of criticism, but its message continues to haunt constitutional theory and analysis. 
by allowing states more discretion to regulate how abortion is delivered while simultaneously reaffirming the basic right of the "essential" Roe. ${ }^{39}$ Alas, Casey did not quell the flames.

The constitutional status of Roe provoked Ely's (1980) entry into the constitutional interpretation wars and was germane to Perry's (1984) Herculean effort to reconcile the Court as both an institution of law and a force of "moral prophesy." Even staunch liberal feminist Ruth Bader Ginsburg observed that the Court had perhaps gone too far in advancing the right to abortion in Roe, at least without waiting for the strategic and normative assistance that evolving public opinion, legislative support, and careful precedential foundation work can bestow (Caplan 2013). The Supreme Court appeared to have taken this lesson to heart by letting state legislatures and lower courts clear the path before it rendered its (albeit divided) decision in Obergefell $v$. Hodges supporting gay marriage in 2015.40 At any rate, the conservative movement that propelled Reagan to power challenged the constitutional underpinnings of Roe as well as the responsive vision of law. As Robert A. Kagan (2005, xxi-xxii) observed,

[t]o conservative politicians, judges, and lawyers, every step toward responsive law was a step away from the certainties of autonomous law. Richard Nixon ran for president in 1968 promising to appoint 'strict constructionists' to the Supreme Court, and ever since, virtually every nomination to the Court, and even to lower federal courts as well, has evoked pitched political battles between Republicans who seek judges who might roll back the 'creative' decisions the Court made in the 1960s and early 1970s, and Democrats who want judges who will preserve those rulings.

Thus, one way to view responsive law is as a mixed bag. On the one hand, it has helped to legitimate and support important human rights causes that majoritarian legislative institutions have suppressed for too long. Expanding the electoral franchise and the rights of equal citizenship to people and groups who have been wrongfully excluded honors the central—and most consensual-promise of liberal democracy. ${ }^{41}$ Paul Berman (1996) has shown the difference between movements bent on moral reform and movements more modestly dedicated to simply broadening political and cultural enfranchisement. Moral reform movements such as Prohibition and various forms of "political correctness" have too often fallen prey to cultural and moral bullying, intolerance of disagreement, and disrespect of democratic self-governance. ${ }^{42}$ On the one hand, one functional role of courts in the American system of separated powers has been as a check against entrenched power that provides access points for outsider groups who lack political power in the political arena-the role of footnote 4 in United States $v$.

39. Planned Parenthood v. Casey, 505 U.S. 833 (1992).

40. Obergefell v. Hodges, 576 U.S. 644 (2015).

41. Justice Earl Warren proclaimed that his Court's most important legacy were the series of decisions expanding equal access to the vote.

42. The Constitution itself is premised on rational acceptance of human imperfection, which is also an aspect of liberty. For example, the preamble speaks of creating "a more perfect Union," not a "perfect Union." On how government based on moral perfection or "utopia" is a recipe for tyranny and totalitarianism, see Pilon 2019. 
Carolene Products for courts that Ely (1980) championed (see also Shapiro 1966). ${ }^{43}$ And sometimes that input is welcomed by elected politicians who prefer that some other institution takes the initiative and any criticism for what might ensue (Graber 2013). ${ }^{44}$

On the other hand, overindulgence in kicking the can over to courts and the bureaucracy not only can threaten the accountability that is essential to democratic legitimacy, but it also bypasses the legislative route that is the main official vehicle of democratic consent and the balancing of competing interests. ${ }^{45}$ One reason the Civil Rights Acts of the 1960s have enjoyed such success is that they were the products of consent forged through legislative give and take; and these acts benefitted from bi-partisan support. Going the legislative route can help for both normative and strategic reasons, especially as the political culture becomes more fragmented and pluralistic. Under-reliance on public opinion and legislative give and take opens the door to discontent and resistance as new interests and concerns arise outside of the guiding lights of responsive law. Public policy in a constitutional regime is not simply about what ends to pursue but also about how to pursue them. (Similarly, constitutional adjudication concerns not just what the Constitution means and how to determine its meaning but also who is properly empowered to make the final decision regarding constitutional meaning (Murphy, Fleming, and Harris 1986). ${ }^{46}$ In many respects, originalist jurisprudence is concerned with the proper allocation of rule-making authority.

In a recent book, Michael Lind (2020) underscores how what James Burnham (1941) famously labeled the new class of a "managerial revolution" has intensified the class conflict that grips many liberal democracies today. Defining the managerial class broadly as those with higher-education degrees—credentialism, American style-Lind discusses how this class, especially those with the most prestigious degrees, has exerted outsized influence in the three decisive realms of culture, politics, and economics. Among other things, such managerial control includes extensive reliance on the power of non-elected institutions consisting of this elite-for example, federal courts (the "juristocracy"), bureaucracies, major corporations, universities, and other leading non-profit organizations - to manage and define affairs outside the turbulent realm of politics. A casualty is the "hollowing out" of consensual democratic politics. ${ }^{47}$ Neoliberal economic policies have diminished large swaths of the economic middle and lower classes, whereas cultural political correctness has been seen as disparaging the values of those who are not

43. United States v. Carolene Products, footnote 4.

44. President James Buchanan's fateful assurance to the nation that the Court's impending Dred Scott $v$. Scott decision, which legitimated slavery, would settle the slavery question once and for all stands as the worst advertisement for this type of shifting of political responsibility to courts.

45. Waldron (1999) addresses this concern in Law and Disagreement, in which he presents a normative theory of legislation in a democratic legal order. One need not go as far as Waldron does regarding the status of judicial review to appreciate the point.

46. The "political question doctrine," which holds that some constitutional questions are to be resolved by non-judicial entities-for example, legislatures, executive leaders, We the People via elections and the exercise of voting and free speech-is predicated on the important question of "who." Federalismappropriate deference to state and local decision making is also an important way to accommodate interests in values in a culturally pluralistic world.

47. Political theorist Sheldon Wolin (1960) labeled the emergent phenomenon of managerial/administrative governance the "sublimation of politics" in his classic book Politics and Vision. 
part of the cultural elite. ${ }^{48}$ Similarly, French economist Thomas Piketty (2018) maintains that the left in the United States and Europe now constitutes the "high-education party" (or "Brahmin left"), whereas the right increasingly speaks for the "workers' party" and the "merchant right."49 The 2016 and 2020 national elections in the United States provide evidence in support of this thesis.

Lind's (2020) analysis highlights tensions on both the left and the right due to the emergence of different forms of populist pressures. Populism entails a distrust of elites and experts, which is both emblematic of the problem at the same time that it is destabilizing (see, for example, Nichols 2017). It calls for due respect because it represents problems that elites have left in the shadows of the polity, but it also encourages demagogues and must be challenged in its own right, as must all policy positions and beliefs in a free society. ${ }^{50}$ As Lind and others acknowledge, populism is more an important symptom than an adequate answer; the nation's policy questions defy simple answers hurled from any political headquarters. And like politics more generally, populism has different ideological dimensions.

Regarding internal party dynamics, each party is undergoing inner ferment. On the right, Trump has deeply disrupted the Republican party, which has a reckoning to make after Trump's postelection behavior and his threat of starting a third party. Meanwhile, the left wrestles with its own form of populist revolt embodied by Bernie Sanders, Alexandria Ocasio-Cortez, and their supporters. Furthermore, more traditional forms of liberalism based on individual rights and universalism are now challenged by "post-liberal" movements within the party (Lilla 2017; Downs 2020) As Ross Douthat (2020) recently wrote in his New York Times column,

[t]he force transforming Western liberalism has many hashtags, many slogans, many admiring and pejorative descriptions, but no single name that everyone can recognize as a singular description of the thing itself. \#MeToo and Black Lives Matter, social justice and intersectionality, anti-racism and the "great awokening." "Cultural Marxism" and "SJWs" [Social Justice Warriors] and "identity politics." Political correctness, of course, and more obscurely "left modernism" and "hyper-liberalism."

The nation appears nervously poised at a fork in the road. On the one hand, Democrats' official control of Congress and the Executive Branch presents at least a theoretical opportunity to push through a strong progressive agenda, which is a hallmark of an ascendant coalition. On the other hand, a rising coalition typically rides the waves of a much stronger electoral current than was evident in the 2020 congressional races. Is it time to make divided government work? CNN's (2020) national election exit poll shows the nation split right down the middle in terms of ideology: 27 percent "liberal,"

48. The outsourcing of jobs, technology, and other resources to China is perhaps the greatest policy blunder governing elites have made over the course of the last three decades, contributing greatly to the rise of populism.

49. See also Lasch 1995.

50. As political theorist Dana Villa $(2001,23)$ writes in Socratic Citizenship, "[t]he implication of Socratic citizenship is that virtually every moral belief becomes false and an invitation to injustice the moment it becomes unquestioned or unquestionable." 
28 percent "conservative," and 45 percent "moderate." Were the Democrats to veer too far left, the likelihood of a backlash in the 2022 midterms would increase, which is what happened in 1994 and 2012, and to the Republicans in 2018. Meanwhile, from a psychological perspective, the citizenry must deal with the implication of the attempted insurrection at the National Capitol Building on January 6, 2021, as well as the almost preternatural effects of a once-in-a-century pandemic, renewed racial unrest, and calls for defunding police. Meanwhile, conspiracy theories and the like have abounded, threatening the "commonly held sense" of reality that Hannah Arendt (1958) considered so necessary to sustaining a viable public realm. Legal common ground is frayed. Along with the internal party ferment mentioned earlier, "Discord and Promise" might be a good epigram for the nation as it enters the new decade.

Let us recall the words at the beginning of this review essay. Tolerating intellectual and political conflict is a hallmark of the United States and of a free society (Huntington 1981). But when does constructive conflict become what Abraham Lincoln called "a house divided"? Whatever transpires, what are the potential implications for US Supreme Court jurisprudence? This question is especially important in the wake of Justice Barrett's arrival on the Court, which has shifted the ideological complexion of the Court further to the right at the same time that Democrats have had considerably less opportunity to pick justices.

\section{REGIME STANDOFF, POLARIZATION, AND CONSTITUTIONAL LAW}

The US Supreme Court must adjudicate in the midst of these and other turbulent forces. How might it navigate these waters? Given the polarization of our era and the overall decline of respect for many institutions, perhaps the most important thing the Court could do is to preserve its own authority in a statesman-like manner while buttressing other institutions of government in a principled manner. ${ }^{51}$ So-called "structural review" in which the Court strives to preserve the balance of powers and the legitimate authority of governmental institutions is a traditional mode of constitutional interpretation that entails taking text, structure, historical context, and strategic wisdom seriously (Murphy, Fleming, and Harris 1986). Historical examples include the new Marshall Court protecting its own institutional power in a strategic fashion in politicized times in Marbury v. Madison; denying the power of the president to close the steel mills by executive order during the Korean War (Youngstown Sheet and Tube Company v. Sawyer); and limiting the power of federal prosecutors to convict defendants of a crime with insufficient mens rea, or guilty mind (Morrissette $v$. United States). ${ }^{52}$ We may read the latter two cases as examples of the

51. Mark Graber (2013, ch. 5) insightfully discusses what he calls the Court's role in preserving "constitutional authority."

52. Marbury v. Madison, 5 U.S. 137 (1803); Youngstown Sheet and Tube Co. v. Sawyer, 343 U.S. 579 (1952); Morrissette v. United States, 342 U.S. 266 (1952). Given the Court's embryonic and uncertain role in the constitutional system, much of Chief Justice John Marshall's tenure (1801-35) involved making decisions that built the Court's authority almost from scratch. He was a fount of law and of strategic acumen, a veritable institutional founder who could be both a lion and a fox-part Blackstone, part Machiavelli's Prince. 
Court striving to reign in the federal government, which had accumulated greater power during the Great Depression and the Second World War. ${ }^{53}$

The US Supreme Court's refusal to grant standing to Texas to sue over the 2020 presidential election results in Pennsylvania, Georgia, Michigan, and Wisconsion provides a recent example of the Court exercising its own prudential institutional protection against political pressure in a manner that also could buttress the authority of electoral institutions (Texas v. Pennsylvania). ${ }^{54}$ Not one of Trump's three appointees agreed with Trump's challenge. A less dramatic way for the Court to maneuver is more tactical: it could muddle along, with swing justices paying due heed to jurisprudential pragmatism in highly politicized cases that is consistent with institutional norms. One thinks of Chief Justice John Roberts joining the liberal faction to uphold the "individual mandate" of the Affordable Care Act in 2012 in National Federation of Independent Businesses $v$. Sibelius. ${ }^{55}$ Such adjudication is not without its own controversy, but it can avoid the controversy of an even stronger sort.

In this spirit, the Supreme Court could follow the advice of such scholars as Daniel Farber and Suzanne Sherry (2002), who urge eschewing the excesses of "grand theory." Jurisprudential pragmatism befits a system of a long-standing divided government, which the 2020 election appears to have perpetuated. Or, consistent with Lind's (2020) position, the Court could nourish judicial modesty and let more decisions involving substantive justice be made by elected representatives and We the People through the exercise of free speech and petition, a solution proffered by such advocates of "popular constitutionalism" as Larry Kramer (2004).

Judicial behavior and jurisprudence can surprise us. Courts properly prize their independence, and presidents and their party loyalists have often been disappointed by justices who end up failing to conform to "litmus tests" upon joining the bench. ("No more Souters!" echoed in the halls of conservative discourse for years.) On the one hand, it is too simplistic to portray the Burger, Rehnquist, and Roberts courts as nothing but agents of a consistent conservative ideology. Nor does the rise of a conservative Supreme Court necessarily mean less judicial "activism," if by that term we mean striking down laws passed by the political process. For example, the Rehnquist Court veered right but consisted of liberals, conservatives, and two swing justices (Sandra Day O'Connor and Anthony Kennedy). As a result, it struck down more federal laws than any Court in history (Keck 2004).

Justices are influenced by arguments presented to them by litigants and by each other, and their reasoning can be shaped by both internal and external strategic concerns. In June 2020, for example, the Supreme Court ruled six to three in a case involving statutory interpretation that the protections of federal anti-discrimination laws apply to lesbian, gay, bisexual, and transgender individuals. Trump appointee Neil Gorsuch wrote the majority opinion, joined by erstwhile conservative Chief Justice

53. On how intellectual, political, and judicial movements strove to appropriately constrain the administrative "Garrison State" coming out of the Second World War and the Cold War, see Friedberg 2000. Friedrich Hayek's (1944) classic book Road to Serfdom played a significant role in this policy debate.

54. Texas v. Pennsylvania, 592 U.S. _ (2020).

55. Affordable Care Act, March 23, 2010, 124 Stat. 119; National Federation of Independent Businesses v. Sibelius, 567 U.S. 519 (2012). 
John Roberts, in Bostock v. Clayton County, Georgia. ${ }^{56}$ Some commentators surmise that the Roberts Court is becoming the "Kagan Court," in reference to the influence of liberal Justice Elena Kagan (Wall Street Journal 2020).

Members of the US Supreme Court are obligated to follow the evident dictates of law regardless of judicial predisposition. A recent example is County of Maui v. Hawaii Wildlife Fund, in which two conservative Trump appointees-Roberts and Kavanaugh — joined the Court's four liberals in ruling against the Trump administration's narrow reading of the Clean Water Act's provision pertaining to waterway runoff. ${ }^{57}$ Another recent example is the Court's unanimous decision to reverse the criminal convictions in the New Jersey "Bridgegate" case, leading to the release of two key staffers for New Jersey Governor Chris Christie. ${ }^{58}$ The holding was dictated by Supreme Court precedent that strictly limited liability for property fraud. ${ }^{59}$ Many other examples of ideological deference to statutory law and precedents exist. ${ }^{60}$

As mentioned, courts prize their constitutional and institutional independencerecall James Madison's (1788) famous call to duty in Federalist no. 51: the office holder must meld his or her own interest with that of the institution. And they must respect such criteria of legal validity as stare decisis and respectable models of constitutional interpretation. Institutional norms and history influence office holders, including judges and justices (Gillman and Clayton 1999). Once doctrine becomes settled, its gravitational pull can be strong. Outside the context of abortion and the non-textual right to privacy, even Scalia said that he would not capriciously dismiss settled doctrine. In a representative observation, legal scholar Thomas M. Keck $(2007,513)$ remarks that "the chief weakness in the regime politics literature has been a tendency to overstate the influence of external political pressure in a way that implies that the justices' actual decisions were inevitable and neglects the possibility of relatively independent institutional action by the Court." In reaction to Justice Roberts's confirmation hearing claim that a justice's duty is simply to "call balls and strikes," Justice Elena Kagan in her own hearing remarked:

If the umpire comes on and says, you know, "I want every call to go to the Phillies," that's a bad umpire. ... [But] the metaphor might suggest to some people that law is a kind of robotic enterprise, that there's a kind of automatic quality to it, that it's easy ... and everything is clear-cut, that that there is no judgment - that there is no judgment in the process. ... [Judges] have to exercise judgment. ... It's not personal views. It's not moral views. It's not political views. (Quoted in Tushnet 2013, 3-4)

56. Bostock v. Clayton County, Ga., 590 U.S. 140 S. Ct. 1731 (2020).

57. County of Maui v. Hawaii Wildlife Fund, 590 U.S. , 140 S. Ct. 146 (2020). Clean Water Act, October 18, 1972, 86 Stat. 816.

58. Kelly v. U.S. et al., 590 U.S. __, 140 S. Ct. 15656 (2020).

59. Arthur Andersen LLP v. United States, 544 U.S. 696 (2005).

60. For a quantitative take on how doctrine ("law") influences free speech jurisprudence, see Kritzer and Richards 2002. On how constitutional tests are a way for the Court to maintain institutional consistency and capacity, see, for example, Coan 2012. The different levels of scrutiny and tests in equal protection doctrine is at least partially explained by judicial capacity and related institutional needs. See Gerstmann 1999. 
On the other hand, the three recent conservative courts have indeed pushed the Supreme Court in more conservative directions. The conservative trend is seen in several important areas, to mention just a few: criminal law and procedure; protecting economic rights in the context of the takings clause campaign finance law; busing and affirmative action; limiting the scope of the right to abortion; religious exercise and establishment; allowing public funds to pay for vouchers for private religious schools if parents so choose independent of public involvement. ${ }^{61}$

The judicial battle over gun rights presents the standoff between political and legal regimes in perhaps its purest form, though even here the US Supreme Court has not reentered the fray in a decade. (Indeed, it declined to hear several appeals involving gun rights in the 2020 term, provoking conservative disconcertion.) Though they left many questions of application open, the Court's District of Columbia v. Heller and McDonald v. City of Chicago decisions made the individual right to bear arms a fundamental constitutional right. ${ }^{62}$ Those two decisions present a classic example of how a burgeoning social, intellectual, and political movement can gain constitutional recognition through the deployment of organizational, intellectual, and litigious strategic acumen that ultimately finds a responsive judicial ear (Levinson 1989; Cornell 2006). One response that Second Amendment advocates have made to liberal or progressive critics of these decisions seems to boil down to a call for equal substantive due process protection, which one could bluntly paraphrase as "you got the right to an abortion, now we get our guns" (to see another version of this line of thinking, see Wilkinson 2009).

The "regime" theory helps to explain what has happened in these cases, though it is necessarily incomplete. To wit, the Burger and Rehnquist Courts did indeed chip away at the Warren Court's criminal procedure decisions (Clayton and Pickerill 2006). In 1983, for example, Justice Rehnquist authored a decision that watered down the standard for determining probable cause of a search warrant based on information provided by an anonymous informant in Illinois v. Gates. ${ }^{63}$ But, in 2000, Rehnquist penned the seven-to-two opinion in Dickerson $v$. United States that reaffirmed the constitutional commitment to Miranda warnings because they "have become embedded in routine police practice to the point where the warnings have become part of our national culture."64 And Scalia-another arch conservative-emerged as a champion of Fourth Amendment rights in general (see, for example, Kyllo v. United States; Arizona v. Hicks), as did Justice Roberts when he joined the Court's

61. See, for example (in chronological order), Payne v. Tennessee, 501 U.S. 808 (1991) (upholding victim impact statements in criminal trials); Lucas v. South Carolina Coastal Council, 505 U.S. 1003 (1992) (just compensation required under the Takings Clause when state law was passed after original purchase that prohibited building on land); Citizens United, 558 U.S. 310 (2010) (striking down laws limiting corporate expenditures on political candidates); Parents Involved in Community Schools v. Seattle, 551 U.S. 701 (2007) (invalidating the use of race in school hiring); Planned Parenthood v. Casey and Gonzales v. Carhart, 550 U.S. 124 (2007) (allowing greater regulation of abortion while preserving the basic right and upholding strong restrictions on late-term abortion); Burwell v. Hobby Lobby Stores, 573 U.S. 682 (2014) (Religious Freedom Restoration Act, November 16, 1993, 107 Stat. 1488, does not allow the Affordable Care Act of 2010 to require a private corporation to provide its employees with contraception coverage despite the owners' religious objections; Zelman v. Simmons-Harris, 536 U.S. 639 (2002) (upholds Cleveland voucher program because choice of school is by parents).

62. District of Columbia v. Heller, 554 U.S. 570 (2008); McDonald v. City of Chicago, 561 U.S. 742 (2010).

63. Illinois v. Gates, 462 U.S. 213 (1983).

64. Dickerson v. United States, 530 U.S. 428 (2000). 
four liberals in ruling that the contents of a cell phone are protected by the Fourth Amendment's warrant requirement (Carpenter v. United States). ${ }^{65}$ A major new area in which the Roberts Court could leave a conservative mark pertains to restraining the power of the administrative state, especially given Gorsuch's and Kavanaugh's views on this issue in the past (see Hamburger 2014; Chemerinsky 2019). (As in Morrissette v. United States, such a decision could be seen as the Court checking bureaucratic growth, a form of structural judicial intervention that even Lind might support. ${ }^{66}$ And though dispute reigns over the extent to which the Roberts Court is a "pro-business" court, its opinions have supported business-oriented rights more fully than its predecessors since the Second World War (compare Conrad 2009 with Pickerill and Clayton 2017). Mark Tushnet's (2013, 6) overall take on the Roberts Court's position in cases that allow for discretionary judgment is representative of many assessments: "[T]hough the picture is mixed, the Roberts Court's decisions correspond to the main constitutional positions associated with the Republican Party of the early twenty-first century." Presidents of both parties got "pretty much what they were looking for" with their respective appointments (6). Especially in cases in which discretionary judgment is given more leeway. ${ }^{67}$

\section{NEW REGIME “SUN": WHEREFORE ART THOU?}

Does 2020 portend a new dominant party system? And how might such eventuality affect the composition of the US Supreme Court? A new Congress controlled by Democrats could act on threats made by presidential primary candidates to replay Roosevelt's reaction circa 2021 by voting to increase the number of justices in order to "pack" the Court in the party's favor. ${ }^{68}$ (Recall that fifteen of the last nineteen justices have been Republican nominees.) Court packing happens to be the theme of the book that Kalman has under contract as I write. That said, packing the Court could throw the lid of Pandora's Box wide open. And the fifty/fifty split in the Senate is not auspicious for such a dramatic move.

The conflict that besets the polity could eventuate in what such futurists as George Friedman (2020) of Geopolitical Futures predicts will be the emergence of a new political regime "sun" a decade or so down the road. Friedman, Lind, and others envision Trump, Sanders, and other populists as symptoms of crisis and ferment, not as meaningful solutions. If Friedman is right, a new dominant party system could emerge at the end of this decade, our present turmoil serving as a stimulant. If so, after a potential initial legal standoff has passed, Kalman's (2017) "Big Bang" could retire to the relative peace associated with the return of the Ecclesiastes school's sun. Does such an auspicious arrangement await in the wings? Or, to borrow from Yeats (1962, I-125), will it be a "rough beast, its hour come round at last," that "slouches towards [Washington] to be born?"

65. Kyllo v. United States, 553 U.S. 27 (2001); Arizona v. Hicks, 480 U.S. 321 (1987); Carpenter v. United States, 585 U.S.

66. Morrissette v. United States.

67. A recent examination of the Roberts Court suggests that, whereas this Court has rendered a surprisingly high number of unanimous decisions, the partisan divide is more evident in the "shadow" decisions that pertain to the granting of certiorari in the first place, where reasons need not be provided (Feldman 2019).

68. See, for example, Millhiser 2020. 


\section{REFERENCES}

Abramowitz, Alan I., and Jennifer McCoy. 2019. "United States. Racial Resentment, Negative Partisanship and Polarization in Trump's America." Annals of the American Academy of Political and Social Science 681: 137-56.

Abramowitz, Alan I., and Steven W. Webster. 2016. "The Rise of Negative Partisanship and the Nationalization of U.S. Elections in the 21st Century.” Electoral Studies 41: 12-22.

Aldrich, John H. 1995. Why Parties? The Origin and Transformation of Political Parties in America. Chicago: University of Chicago Press.

Arendt, Hannah. 1958. The Human Condition. Chicago: University of Chicago Press.

Arkes, Hadley. 2002. Natural Rights and the Right to Choose. Cambridge, UK: Cambridge University Press.

Bell, Daniel. 1960. The End of Ideology: On the Exhaustion of Political Ideas in the 1950s. Glencoe, IL: Free Press.

Berman, Paul. 1996. A Tale of Two Utopias: The Political Journey of the Generation of 1968. New York: Norton.

Berger, Raoul. 1977. Government by Judiciary: The Transformation of the Fourteenth Amendment. Cambridge, MA: Harvard University Press.

Berns, Walter. 1982. "Judicial Review and the Rights and Laws of Nature." Supreme Court Review 1982: 49-83.

Bickel, Alexander M. 1962. The Least Dangerous Branch: The Supreme Court at the Bar of Politics. Indianapolis: Bobbs-Merrill.

Binder, Sarah, and Forrest Maltzman. 2009. Advise and Consent: The Struggle to Reshape the Federal Judiciary. Washington, DC: Brookings Institution.

Bishop, Bill, with Robert G. Cushing. 2008. The Big Sort: Why the Clustering of Like-Minded Americans Is Tearing Us Apart. New York: Houghton Mifflin Harcourt.

Bobbitt, Philip. 1982. Constitutional Fate: Theory of the Constitution. New York: Oxford University Press.

Brinkley, Alan. 1995. The End of Reform: New Deal Liberalism in Recession and War. New York: Alfred A. Knopf.

Bruce, Tricia. 2020. How Americans Understand Abortion: A Comprehensive Interview Study of Abortion Attitudes in the United States. South Bend, IN: McGrath Institute for Church Life, University of Notre Dame.

Burnham, James. 1941. The Managerial Revolution: What Is Happening in the World. New York: John Day Company.

Burnham, Walter Dean. 1970. Critical Elections and the Mainstream of American Politics. New York: Norton.

Caplan, Lincoln. 2013. “Ginsburg's Roe v. Wade Blind Spot.” New York Times, May 13. https:// takingnote.blogs.nytimes.com/2013/05/13/ginsburgs-roe-v-wade-blindspot/.

Chemerinsky, Erwin. 2019. "How the Roberts Court Could Alter the Administrative State." American Bar Association Journal, September 4. https://www.abajournal.com/news/article/chemerinsky-theroberts-court-could-alter-the-administrative-state.

Choper, Jesse H. 1980. Judicial Review and the National Political Process: A Functional Consideration of the Role of the Supreme Court. Chicago: University of Chicago Press.

Clayton, Cornell W., and J. Mitchell Pickerill. 2006. "The Politics of Criminal Justice: How the New Right Regime Shaped the Rehnquist Court's Criminal Justice Jurisprudence.” Georgetown Law Journal 94: 1385-1425.

CNN. 2020. "Exit Poll 2020: National Results, Ideology." https://www.cnn.com/election/2020/exitpolls/president/national-results/7.

Coan, Andrew. 2012. "Judicial Capacity and the Substance of Constitutional Law." Yale Law Journal 122: 422-58.

Cohen, Marty, David Karol, Hans Noel, and John Zaller. 2008. The Party Decides: Presidential Nominations before and after Reform. Chicago: University of Chicago Press. 
Conrad, Robin S. 2009. "The Roberts Court and the Myth of a Pro-Business Bias." Santa Clara Law Review 49: 997-1017.

Cornell, Saul. 2006. A Well Regulated Militia: The Founding Fathers and the Origins of Gun Control in America. Oxford: Oxford University Press.

Corwin, Edward S. 1948. Liberty against Government: The Rise, Flowering, and Decline of a Famous Juridical Concept. Westport, CT: Greenwood Press.

Cox, Archibald. 1976. The Role of the Supreme Court in American Government. New York: Oxford University Press.

Douthat, Ross. 2020. "The Tom Cotton Op-Ed and the Cultural Revolution: How Liberalism, and the Liberal Media Are Changing before Our Eyes." New York Times, June 12. https://www.nytimes. com/2020/06/12/opinion/nyt-tom-cotton-oped-liberalism.html.

Downs, Donald Alexander. 1989. The New Politics of Pornography. Chicago: University of Chicago Press.

1999. Cornell '69: Liberalism and the Crisis of the American University. Ithaca, NY: Cornell University Press.

- 2020. Free Speech and Liberal Education: A Plea for Intellectual Diversity and Tolerance. Washington, DC: Cato Institute.

Dyer, Justin Buckley. 2013. Slavery, Abortion, and the Politics of Constitutional Meaning. New York: Cambridge University Press.

Ely, John Hart. 1980. Democracy and Distrust: A Theory of Judicial Review. Cambridge, MA: Harvard University Press.

Epp, Charles R. 1998. The Rights Revolution: Lawyers, Activists, and Supreme Courts in Comparative Perspective. Chicago: University of Chicago Press.

Epstein, Lee, and Jeffrey A. Segal. 2005. Advise and Consent: The Politics of Judicial Appointments. New York: Oxford University Press.

Epstein, Lee, and Posner, Eric. 2018. "If the Supreme Court Is Nakedly Political, Can It Be Just? New York Times, July 9. https://www.nytimes.com/2018/07/09/opinion/supreme-court-nominee-trump.html.

Farber, Daniel A., and Suzanna Sherry. 2002. Desperately Seeking Certainty: The Misguided Quest for Constitutional Foundations. Chicago: University of Chicago Press.

Farber, David R. 2010. The Rise and Fall of Modern Conservatism: A Short History. Princeton, NJ: Princeton University Press.

Feeley, Malcolm M. 1992. "Hollow Hopes, Flypaper, and Metaphors." Law EO Social Inquiry 17: 745-60.

Feldman, Adam. 2019. "Empirical SCOTUS: Amid Record-Breaking Consensus, the Justices' Divisions Still Run Deep.” SCOTUS Blog, February 25. https://www.scotusblog.com/2019/02/ empirical-scotus-amid-record-breaking-consensus-the-justices-divisions-still-run-deep/.

Friedberg, Aaron. 2000. In the Shadow of the Garrison State: America's Anti-Statism and Its Cold War Strategy. Princeton, NJ: Princeton University Press.

Friedman, George. 2020. The Storm before the Calm: America's Discord, the Coming Crisis of the 2020s, and the Triumph Beyond. New York: Doubleday.

Friedman, Lawrence M. 1985. Total Justice. New York: Russell Sage Foundation.

Fukuyama, Francis. 1992. The End of History and the Last Man. New York: Free Press.

Gerstmann, Evan. 1999. The Constitutional Underclass: Gays, Lesbians, and the Failure of Class-Based Equal Protection. Chicago: University of Chicago Press.

Gillman, Howard. 1993. The Constitution Besieged: The Rise and Decline of Lochner Era Police Powers Jurisprudence. Durham, NC: Duke University Press.

Gillman, Howard, and Cornell Clayton. 1999. The Supreme Court in American Politics: New Institutionalist Interpretations. Lawrence: University Press of Kansas.

Graber, Mark. 2013. A New Introduction to American Constitutionalism. Oxford: Oxford University Press.

Graham, Fred P. 1972. The Self-Inflicted Wound. New York: Macmillan.

Grey, Thomas C. 1978. "Origins of the Unwritten Constitution: Fundamental Law in American Revolutionary Thought." Stanford Law Review 30: 843-93

Hacker, Jacob, and Paul Pierson. 2019. "The Republican Devolution: Partisanship and the Decline of American Governance." Foreign Affairs 98, no. 4: 42-50. 
Hamburger, Philip. 2014. Is Administrative Law Unlawful? Chicago: University of Chicago Press. Hayek, Friedrich. 1944. Road to Serfdom. Chicago: University of Chicago Press.

Hegel, G. W. F. 1952. Philosophy of Right. Translated by T. M. Knox. Chicago: Encyclopedia of Brittanica Great Books.

Hopkins, Daniel J. 2018. The Increasingly United States: How and Why American Political Behavior Became Nationalized. Chicago: University of Chicago Press.

Horowitz, Donald L. 1977. The Courts and Social Policy. Washington, DC: Brookings Institution.

Huntington, Samuel. 1981. American Politics: The Promise of Disharmony. Cambridge, MA: Belknap Press.

Jacobsohn, Gary. 1984. "E.T.: The Extra-Textual in Constitutional Interpretation." Constitutional Commentary 1: 21-42.

Judis, John B. 2002. The Emerging Democratic Majority. New York: Scribner.

Kagan, Robert. A. 2005. "Introduction." In Law and Society in Transition: Toward Responsive Law, edited by Phillipe Nonet and Philip Selznick, vii-xxv. 2nd ed. New Brunswick, NJ: Transaction Publishers.

—. 2012. The World America Made. New York: Alfred A. Knopf.

Kalman, Laura. 1996. The Strange Career of Legal Liberalism. New Haven, CT: Yale University Press. 2010. Right Star Rising: A New Politics, 1974-1980. New York: Norton.

2017. The Long Reach of the Sixties: LBJ, Nixon, and the Makings of the Contemporary Supreme Court. New York: Oxford University Press.

Keck, Thomas M. 2004. The Most Activist Supreme Court in History: The Road to Modern Judicial Conservatism. Chicago: University of Chicago Press.

— 2007. "Party Politics or Judicial Independence? The Regime Politics Literature Hits the Law Schools." Law EO Social Inquiry 32: 511-44.

Kennan, George F. 1967-72. Memoirs. Vols. 1 and 2. Boston: Little, Brown.

Kersch, Kenneth Ira. 2004. Constructing Civil Liberties: Discontinuities in the Development of American Constitutional Law. Cambridge, UK: Cambridge University Press.

Klein, Ezra. 2020. Why We're Polarized. New York: Avid Reader Press.

Kramer, Larry D. 2004. The People Themselves: Popular Constitutionalism and Judicial Review. New York: Oxford University Press.

Kritzer, Herbert M., and Mark J. Richards. 2002. "Jurisprudential Regimes in Supreme Court Decision Making." American Political Science Review 96: 305-20.

Lasch, Christopher. 1995. The Revolt of the Elites: And the Betrayal of Democracy. New York: W. W. Norton.

Lee, Francis L. 2016. Insecure Majorities: Congress and the Perpetual Campaign. Chicago: University of Chicago Press.

Leuchtenburg, William Edward. 1996. The Supreme Court Reborn: The Constitutional Revolution in the Age of Roosevelt. New York: Oxford University Press.

Levendusky, Matthew S. 2010. The Partisan Sort: How Liberals Became Democrats and Conservatives Became Republicans. Chicago: University of Chicago Press.

Levinson, Sanford. 1989. "The Embarrassing Second Amendment." Yale Law Journal 97: 637-59.

Lilla, Mark. 2017. The Once and Future Liberal: After Identity Politics. New York: Harper Collins.

Lind, Michael. 2020. The New Class War. Saving America from the Managerial Elite. New York: Portfolio/Penguin.

Lippmann, Walter. 1929. A Preface to Morals. New York: Macmillan.

Lubell, Samuel. 1965. The Future of American Politics. 3rd ed. New York: Harper Colophon.

Luker, Kristin. 1984. Abortion and the Politics of Motherhood. Berkeley: University of California Press. Madison, James. 1788. "The Structure of the Government Must Furnish the Proper Checks and Balances between the Different Departments." Federalist Papers no. 51, February 8.

McCann, Michael W. 1986. Taking Reform Seriously: Perspectives on Public Interest Liberalism. Ithaca, NY: Cornell University Press.

. 1992. "Reform Litigation on Trial." Law EF Social Inquiry 17: 715-43.

Meese, Edwin. 1986. "The Supreme Court of the United States: Bulwark of a Limited Constitution." Address in Washington, DC, on July 9, 1985. Reprinted in South Texas Law Review 27: 455-66. 
Meiklejohn, Alexander. 1965. Free Speech and Its Relation to Self-Government in Political Freedom: The Constitutional Powers of the People. New York: Harper.

Millhiser, Ian. 2020. "The Most Radical Democratic Plan to Fix the Supreme Court Yet." Vox, January 31. https://www.vox.com/2020/1/31/21115114/court-packing-supreme-court-tom-steyer-mitchmcConnell.

Murphy, Walter F., James E. Fleming, and William F. Harris II. 1986. American Constitutional Interpretation. Mineola, NY: Foundation Press.

New York Times. 1964. "News Analysis: What Goldwater Lost. Voters Rejected His Candidacy, The Conservative Cause, and the G.O.P." November 4.

Nichols, Tom. 2017. The Death of Expertise: The Campaign Against Established Knowledge and Why It Matters. New York: Oxford University Press.

Nonet, Phillipe, and Philip Selznick. 2005. Law and Society in Transition: Toward Responsive Law. 2nd ed. New Brunswick, NJ: Transaction Publishers.

O'Brien, Neil A. 2019. Before Reagan: The Development of Abortion's Partisan Divide. Perspectives on Politics. American Political Science Association. Cambridge, MA: Cambridge University Press.

O'Neill, William P. 1971. Coming Apart: An Informal History of America in the 1960s. New York: Times Books.

Oreskes, Naomi. 2019. Why Trust Science? Princeton, NJ: Princeton University Press.

Perlstein, Rick. 2001. Before the Storm: Barry Goldwater and the Unmaking of the American Consensus. New York: Hill and Wang.

- 2014. The Invisible Bridge: The Fall of Nixon and the Rise of Reagan. New York: Simon and Schuster.

- 2020. Reaganland: America's Right Turn, 1976-1980. New York: Simon and Shuster.

Perry, Michael J. 1984. The Constitution, the Courts, and Human Rights. New Haven, CT: Yale University Press.

Pew Research Center. 2017. "The Shift in the American Public's Political Values. Political Polarization, 1994-2017." https:/www.pewresearch.org/politics/interactives/political-polarization-1994-2017/.

Phillips, Kevin P. 1969. The Emerging Republican Majority. New Rochelle, NY: Arlington House.

Pickerill, J. Mitchell, and Cornell W. Clayton. 2017. "The Roberts Court and Economic Issues in an Era of Polarization." Case Western Law Review 67: 693-720.

Piketty, Thomas. 2018. "Brahmin Left vs. Merchant Right: Rising Inequality and the Changing Structure of Political Conflict." World Inequality Lab Working Papers. https://hal-pse. archives-ouvertes.fr/hal-02878211.

Pilon, Juliana Geran. 2019. The Utopian Conceit and the War on Freedom. Washington, DC: Academia Press.

Randall, Richard. 1989. Freedom and Taboo: Pornography and the Politics of a Divided Self. Berkeley: University of California Press.

Rawls, John. 1971. A Theory of Justice. Cambridge, MA: Harvard University Press.

Rosenberg, Gerald N. 1991. The Hollow Hope: Can Courts Bring About Social Change? Chicago: University of Chicago Press.

_ 1992. "Hollow Hopes and Other Aspirations: A Reply to Feeley and McCann." Law E Social Inquiry 17: 761-78.

Roy, Olivier. 2020. Is Europe Christian? Oxford: Oxford University Press.

Rubenfeld, Jed. 1989. "The Right to Privacy." Harvard Law Review 102: 737-807.

Schlesinger, Arthur M., Jr. 1949. The Vital Center: The Politics of Freedom. Boston: Houghton Mifflin.

Shafer, Byron E. 2003. The Two Majorities and the Puzzle of Modern American Politics. Lawrence: University Press of Kansas.

Shapiro, Martin M. 1966. Freedom of Speech: The Supreme Court and Judicial Review. Englewood Cliffs, NJ: Prentice-Hall.

. 1986. "The Supreme Court's Return to Economic Regulation." Studies in American Political Development 1: 91-141.

Siegan, Bernard H. 1980. Economic Liberties and the Constitution. Chicago: University of Chicago Press.

- 2017. Economic Liberties and the Constitution. London: Routledge. 
Skrentny, John David. 1996. The Ironies of Affirmative Action: Politics, Culture, and Justice in America. Chicago: University of Chicago Press.

Skowronek, Stephen. 1997. The Politics Presidents Make: Leadership From John Adams to Bill Clinton. 2nd ed. Cambridge, MA: Harvard University Press.

Steinfels, Peter. 1979. The Neoconservatives: The Men Who Are Changing American Politics. New York: Simon and Schuster.

Stone, Geoffrey R., 2020. Democracy and Equality: The Enduring Constitutional Vision of the Warren Court. New York: Oxford University Press.

Stuntz, William. 2011. The Collapse of American Criminal Justice. Cambridge, MA: Harvard University Press.

Suri, Jeremi. 2007. Henry Kissinger and the American Century. Cambridge, MA: Harvard University Press.

Teles, Steven Michael. 2008. The Rise of the Conservative Legal Movement: The Battle for the Control of the Law. Princeton, NJ: Princeton University Press.

Thompson, Benjamin. 2016. "The Voters Decide," Strategery, March 2.

Thomson, Judith Jarvis. 1971. "A Defense of Abortion." Philosophy and Public Affairs 1, no. 1: 47-66.

Tocqueville, Alexis de. (1835) 1961. Democracy in America. Translated by Henry Reeves. Vols. 1 and 2. New York: Schocken Books.

Tushnet, Mark V. 1999. Taking the Constitution Away from the Courts. Princeton, NJ: Princeton University Press.

- 2013. In the Balance: Law and Politics on the Roberts Court. New York: W. W. Norton.

Unger, Robeto Mangabeira. 1976. Law in Modern Society: Toward a Criticism of Social Theory. New York: Free Press.

Villa, Dana. 2001. Socratic Citizenship. Princeton, NJ: Princeton University Press.

Waldron, Jeremy. 1999. Law and Disagreement. Oxford: Clarendon Press.

Wall Street Journal. 2020. “Another Win for the Kagan Court. Editorial.” June 16. https://www.wsj. com/articles/another-win-for-the-kagan-court-11592264430.

Watson, Richard L., Jr. 1963. "The Defeat of Judge Parker: A Study in Pressure Groups and Politics." Mississippi Valley Historical Review 50, no. 2: 213-34.

Weinrib, Ernest J. 1995. The Idea of Private Law. Cambridge, MA: Harvard University Press.

Whittington, Keith E. 1999. Constitutional Interpretation: Textual Meaning, Original Meaning, and Judicial Review. Lawrence: University Press of Kansas.

Wilkinson, Harvie J., III. 2009. "Of Guns, Abortions, and the Unraveling Rule of Law." Virginia Law Review 95: 253-323.

Wolin, Sheldon S., 1960. Politics and Vision: Continuity and Innovation in Western Political Thought. Boston: Little, Brown.

Yeats, William Butler. 1962. "The Second Coming." In Chief Modern Poets of England and America, edited by Dewitt Sanders, John Herbert Nelson, and M. L. Rosenthal. 4th ed. New York: Macmillan Company. 